\title{
Betrixaban: An Oral Factor Xa Inhibitor
}

\author{
Ohoud Almalki* \\ King Fahad Medical City, Riyadh, Saudi Arabia
}

\begin{abstract}
Betrixaban is the first and only oral once-daily factor Xa inhibitor, approved by the FDA under Priority Review in June 2017, for extended prophylaxis of VTE in acutely ill medical patients. It has been approved based on data from a multinational APEX study that included 7513 patients at 460 sites. A benefit of betrixaban was observed in patients with an elevated d-dimer level or an age of at least 75 years, and in the overall population. Major bleeding was not statistically different between groups in the overall safety population. Overall, currently available data suggest that betrixaban is a safe and effective option for extended duration VTE prophylaxis in medically ill patients at risk for VTE during their transition from hospital to home.
\end{abstract}

\section{Introduction}

Venous thromboembolism (VTE) occurs in all groups of hospitalized patients [1]. The prevalence of deep vein thrombosis (DVT) in the absence of prophylaxis is estimated to be in the range of $10-20 \%$ among general medical patients. Moreover, the risk is as high as $20-50 \%$ among patients admitted for stroke and $40-60 \%$ among orthopedic surgical patients [2].

In addition to the background risk factors present in hospitalized, medically ill patients, such as advanced age, cancer, a history of VTE, and the presence of an acute infectious disease, among others [3], hospitalization due to acute medical illness per se increases the risk of VTE eightfold [4].

Existing evidence has shown the benefit of in-hospital prophylaxis, which results in up to a 50\% reduction in in-hospital VTE risk [5]. However, in-hospital prophylaxis has not been associated with a reduction in post-discharge VTE, which is linked to up to $74 \%$ of total VTE events, and they were more likely to occur in the first 29 days after discharge [6-8]. Indeed, the higher the number of risk factors, the higher the incidence of developing postdischarge VTE events $(2.9 \% \leq$ 2 risk factors vs. $6.1 \%$ for $\geq 3$ risk factors vs. $8.7 \%$ for $\geq 4$ risk factors; $\mathrm{P}=0.01) .37$ [9].

It has been suggested that the thrombotic process may already begin in medical patients prior to admission, as they might have been ill for days or weeks before being referred to a hospital [1]. Moreover, inflammation-induced thrombosis has been reported with certain acute medical illnesses (e.g., malignancies, acute coronary syndromes, heart failure, chronic kidney disease, and respiratory diseases). Such illnesses predispose patients to thrombosis following discharge due to a prolonged increase in inflammatory markers [10-15]. Thus, inhospital prophylaxis might not be optimal in medical patients unless it is continued after discharge.

Three major studies have been published on the possible benefits of extended-duration prophylaxis in medical patients, with conflicting results. The first double-blinded, double-dummy, placebo-controlled trial (ADOPT) showed that extended prophylaxis with apixaban in medically ill patients was not superior to short-term prophylaxis with enoxaparin in reducing postdischarge VTE. Of note, major bleeding was higher in the extended prophylaxis group than in the short-term prophylaxis group [16]. EXCLAIM - another randomized, parallel, placebo-controlled trial-revealed the benefit of extended prophylaxis in a subanalysis of elderly patients ( $>75$ years), women, and patients with level I immobility, but at the cost of an increased rate of major bleeding [17]. The third randomized controlled trial (MAGELLAN) reported that extended-duration rivaroxaban reduced the risk of VTE, at the expense of significantly higher rates of major bleeding [18]. The designs and results of key clinical trials on extended-duration prophylaxis for medical patients are described in Table 1.

A recent meta-analysis by Sharma et al. that included the three above studies $(\mathrm{N}=20362)$ noted that patients on extended prophylaxis had a lower composite event rate comprising mortality and symptomatic and asymptomatic PE and DVT (RR: 0.75, 95\% CI: 0.64-0.88, NNT: $320)$. Extended prophylaxis therapy also showed a significant increase in the event rate of major bleeds (RR: $2.68,95 \% \mathrm{CI}: 1.78-4.05, \mathrm{NNH}$ : 194). However, extended prophylaxis showed no overall benefit in the subanalyses using only symptomatic thromboembolic events (DVT and PE), mortality, and major bleeding (RR: 0.69, 95\% CI: -0.25-1.91) [19].

Betrixaban is the first factor Xa inhibitor, approved by the FDA under Priority Review, for hospital and extended duration VTE prophylaxis in hospitalized acutely ill medical patients.

\section{Betrixaban}

\section{Mechanism of action}

Betrixaban is a direct and selective factor Xa (FXa) inhibitor that decreases thrombin generation (TG) via blocking the active site of FXa, which translates into low free FXa and prothrombinase activity. It does not require a cofactor (such as antithrombin III) for activity and has no direct effect on platelet aggregation [20].

Correspondence to: MOhoud Almalki, King Fahad Medical City, Riyadh, Saudi rabia, Tel: +966 11288 9999; E-Mail: ohoud.almalki@yahoo.com

Keywords: betrixaban, extended-duration, prophylaxis, venous thromboembolism, hospitalized, medical patients

Received: October 06, 2017; Accepted: October 24, 2017; Published: October 26, 2017 
Table 1. Pharmacokinetic characteristics of betrixaban [20].

\begin{tabular}{|l|l|}
\hline Characteristic & Value \\
\hline Bioavailability for an 80 -mg dose, $\%$ & 34 \\
\hline Time to peak $\mathrm{h}$ & $3-4$ \\
\hline $\begin{array}{l}\text { Time to steady-state (without an initial } \\
\text { loading dose), } \mathrm{d}\end{array}$ & 6 \\
\hline Distribution $\left(\mathrm{V}_{\mathrm{d}}\right), \mathrm{L} / \mathrm{kg}$ & $\sim 32$ \\
\hline In vitro-plasma protein binding, \% & 60 \\
\hline Half-life elimination, $\mathrm{h}$ & $\sim 19-27$ \\
\hline & $\begin{array}{l}- \text { Unchanged (predominantly)- Inactive } \\
\text { major metabolites } ~ 15-18 ~(C Y P- \\
\text { independent hydrolysis)- Minor (CYP: } \\
1 \mathrm{~A} 1,1 \mathrm{~A} 2,2 \mathrm{~B} 6,2 \mathrm{C} 9,2 \mathrm{C} 19,2 \mathrm{D} 6, \text { and 3A4) } \\
\sim<1\end{array}$ \\
\hline Metabolism, \% & Yes \\
\hline P-glycoprotein substrate & $\begin{array}{l}\text { Urine: } 11 \\
\text { Feces: } 85\end{array}$ \\
\hline Excretion, $\%$ & \\
\hline CYP: cytochrome P450 & \\
\hline
\end{tabular}

\section{Pharmacodynamics and pharmacokinetics}

Cardiac Electrophysiology: Betrixaban administration results in a concentration-dependent increase in the QTc interval. The mean QTc prolongation in relation to betrixaban concentration is predicted to be $4 \mathrm{~ms}$ and $13 \mathrm{~ms}$ for $80 \mathrm{mg}$ of betrixaban and for a 4.7-fold increase in exposure, respectively [20].

Dose-ranging study: In the single ascending dose study, a twofold increase in the dose using the anticipated therapeutic dose range resulted in a three-fold increase in the exposure. Moreover, repeated dosing resulted in a two-fold increase in betrixaban exposure [20]. The pharmacokinetic characteristics of betrixaban are summarized in Table 2.

\section{FDA approved indications}

For VTE prophylaxis in hospitalized adult patients who are admitted for acute medical illness and are at risk for thromboembolic complications due to moderate or severe restricted mobility and other risk factors for VTE. However, this indication cannot be extended to patients with prosthetic heart valve diseases because it has not been studied in this population [20].

\section{Precautions}

Betrixaban increases the risk of bleeding that may result in serious and potentially fatal bleeding. The risk of bleeding increases when betrixaban is given concomitantly with other drugs that affect hemostasis, such as antiplatelet agents, other anticoagulants, thrombolytic agents, selective serotonin reuptake inhibitors, serotonin norepinephrine reuptake inhibitors, and nonsteroidal antiinflammatory drugs (NSAIDs) [20].

\section{Contraindications}

Betrixaban is contraindicated in case of active pathological bleeding and severe hypersensitivity reaction to betrixaban [20].

\section{Warnings/ precautions}

In case of active bleeding, betrixaban should be discontinued immediately and the need for blood replacement should be considered. There is no established antidote to reverse the anticoagulant effect of betrixaban, which is anticipated to persist for at least 72 hours after the most recent administered dose. Protamine sulfate, vitamin $\mathrm{K}$, and tranexamic acid are not expected to reverse betrixaban's anticoagulant activity. The role of hemodialysis in removing betrixaban from the body is still unknown [20].
Spinal/epidural anesthesia or puncture: In order to reduce the risk of developing an epidural or spinal hematoma, which can result in long-term or permanent paralysis, the epidural catheter should not be removed sooner than 72 hours after the last administered dose of betrixaban. Also, betrixaban should not be administered sooner than 5 hours after catheter removal. The administration of betrixaban should be delayed for 72 hours if traumatic puncture occurs (Table 3) [20].

\section{Efficacy and tolerability}

Cohen, et al. conducted a randomized clinical trial that examined the efficacy and safety of extended-duration betrixaban compared to a standard regimen of enoxaparin for the prevention of VTE in acutely ill medical patients after hospital discharge. The primary efficacy outcome was a composite of asymptomatic proximal DVT between day 32 and day 47, symptomatic proximal or distal DVT, symptomatic nonfatal pulmonary embolism, or death from VTE between day 1 and day 42 . The secondary efficacy outcomes were 1) a composite of symptomatic venous thromboembolism through day 42 and 2) the primary efficacy outcome with the replacement of death from venous thromboembolism by death from any cause. The safety outcome was the occurrence of major bleeding at any point until 7 days after the discontinuation of all study medications [21].

The protocol was modified to include the presence of an elevated $\mathrm{d}$-dimer level or an age of at least 75 years as an entry criterion. Patients were stratified into two cohorts within the overall study population. Cohort 1 was defined as patients who had an elevated baseline d-dimer level, and cohort 2 was defined as the patients in cohort 1 plus those who were 75 years of age or older [21].

The intervention used was $40 \mathrm{mg}$ enoxaparin daily plus oral placebo daily. This was examined against subcutaneous placebo daily plus oral betrixaban. Doses of betrixaban and enoxaparin were reduced if patients had severe renal insufficiency or received a concomitant P-glycoprotein inhibitor for betrixaban only [21].

In cohort $1,6.9 \%$ and $8.5 \%$ of the patients in the betrixaban group and enoxaparin group, respectively, developed the primary efficacy outcome (RR in the betrixaban group: 0.81 ; $95 \%$ CI: $0.65-1.00$ ). In cohort 2, the primary efficacy outcome occurred in $5.6 \%$ and $7.1 \%$ of the betrixaban group and the enoxaparin group, respectively (RR: 0.80 ; $95 \%$ CI: $0.66-0.98)$. In the overall population, the primary efficacy outcome was reported in $5.3 \%$ and $7.0 \%$ of the patients in the betrixaban and enoxaparin groups, respectively (RR: 0.76; 95\% CI: 0.63-0.92). In the overall population, $0.9 \%$ and $1.5 \%$ of the patients in the betrixaban and enoxaparin groups, respectively, developed symptomatic venous thromboembolism (RR: 0.64; 95\% CI: 0.42-0.98). The second secondary efficacy outcome, defined as the primary efficacy outcome with the replacement of death from venous thromboembolism by death from any cause, was reported in $9.2 \%$ and $10.8 \%$ of the betrixaban group and

Table 2. Dosing and administration [20]. "Computed by Cockcroft-Gault using actual body weight

"e.g., amiodarone, azithromycin, verapamil, ketoconazole, clarithromycin

\begin{tabular}{|l|l|}
\hline Normal renal function & $\begin{array}{l}\text { An initial single dose of } 160 \mathrm{mg} \text {, followed } \\
\text { by } 80 \mathrm{mg} \text { once daily for } 35 \text { to } 42 \text { days }\end{array}$ \\
\hline In sever renal impairment (defined as crcl $\geq 15$ to $<30 \mathrm{ml} / \mathrm{min})^{*}$
\end{tabular}


Table 3. Key clinical trials [16-18].

\begin{tabular}{|c|c|c|c|c|c|}
\hline \multirow{2}{*}{ Trial name } & \multirow{2}{*}{ Study design } & \multicolumn{2}{|l|}{ Key criteria } & \multirow{2}{*}{$\begin{array}{l}\text { Primary } \\
\text { Efficacy Endpoint }\end{array}$} & \multirow{2}{*}{$\begin{array}{l}\text { Safety } \\
\text { Endpoint }\end{array}$} \\
\hline & & Inclusion & Exclusion & & \\
\hline ADOPT & $\begin{array}{l}\text { International, multicenter, } \\
\text { randomized, } \\
\text { double-blind, controlled study }\end{array}$ & $\begin{array}{l}\text { Acutely ill patients who had } \\
\text { congestive heart failure or } \\
\text { respiratory failure or other } \\
\text { medical disorders and at } \\
\text { least one additional risk } \\
\text { factor for VTE and who were } \\
\text { hospitalized with an expected } \\
\text { stay of at least } 3 \text { days }\end{array}$ & $\begin{array}{l}\text { Confirmed } \\
\text { VTE; active bleeding, } \\
\text { high risk for bleeding, } \\
\text { contraindication to } \\
\text { enoxaparin or apixaban; } \\
\text { active liver disease, anemia } \\
\text { or thrombocytopenia; severe } \\
\text { renal disease, taking two or } \\
\text { more antiplatelet agents or } \\
\text { aspirin at a dose higher than } \\
165 \text { mg per day }\end{array}$ & $\begin{array}{l}\text { Composite during the } 30 \text {-day } \\
\text { treatment period of death } \\
\text { related to VTE }\end{array}$ & $\begin{array}{l}\text { Major bleeding } \\
\text { (During treatment period) }\end{array}$ \\
\hline $\begin{array}{l}\text { Apixaban } 2.5 \mathrm{mg} \\
\text { BID } \\
(\mathrm{N}: 2211)\end{array}$ & - & - & - & $2.71 \%$ & $0.47 \%$ \\
\hline $\begin{array}{l}\text { Enoxaparin } \\
40 \mathrm{mg} \text { daily } \\
(\mathrm{N}: 2284)\end{array}$ & - & - & - & $3.06 \%$ & 0.19 \\
\hline Statistics & - & - & - & $\begin{array}{l}\text { RR with apixaban }(95 \% \mathrm{CI}) \text { : } \\
0.87(0.62 \text { to } 1.23)\end{array}$ & $\begin{array}{l}\text { RR with apixaban }(95 \% \mathrm{CI}) \text { : } \\
2.58(1.02 \text { to } 7.24)\end{array}$ \\
\hline MAGELLAN & $\begin{array}{l}\text { Randomized, double-blind, } \\
\text { active-comparator-controlled, } \\
\text { multinational clinical trial }\end{array}$ & $\begin{array}{l}40 \text { years of age or older, } \\
\text { had been hospitalized for } \\
\text { a specified acute medical } \\
\text { illness for less than } 72 \text { hours } \\
\text { before randomization, and } \\
\text { had reduced mobility }\end{array}$ & $\begin{array}{l}\text { Active bleeding, high risk for } \\
\text { bleeding, contraindication to } \\
\text { enoxaparin or rivaroxaban, } \\
\text { severe renal or hepatic } \\
\text { disease, HIV infection } \\
\text { at screening, sustained } \\
\text { uncontrolled systolic blood } \\
\text { pressure, Cardiogenic or } \\
\text { septic shock with the need for } \\
\text { vasopressor(s) }\end{array}$ & $\begin{array}{l}\text { Composite of asymptomatic } \\
\text { proximal deep-vein } \\
\text { thrombosis, symptomatic } \\
\text { proximal or distal deep-vein } \\
\text { thrombosis, symptomatic } \\
\text { nonfatal pulmonary } \\
\text { embolism, or death related } \\
\text { to venous thromboembolism } \\
\text { from day } 1 \text { to day } 10 \text { and } \\
\text { from day } 10 \text { to day } 35\end{array}$ & Clinically relevant bleeding \\
\hline $\begin{array}{l}\text { Rivaroxaban } 10 \mathrm{mg} \text { daily } \\
\text { (N: } 2938 \text {, for primary efficacy } \\
\text { outcome at D10) } \\
\text { (N: } 2967 \text { ) for primary } \\
\text { efficacy outcome at D35) } \\
\text { (N: } 3997 \text { for safety outcome) }\end{array}$ & - & - & - & $\begin{array}{l}\text { Day10: } 2.7 \% \\
\text { Day 35: } 4.4 \%\end{array}$ & $\begin{array}{l}\text { Day10: } 2.8 \% \\
\text { Day 35: } 4.1 \%\end{array}$ \\
\hline $\begin{array}{l}\text { Enoxaparin, } \\
40 \text { mg daily } \\
\text { (N: } 2993 \text { for primary efficacy } \\
\text { outcome at D10) } \\
(\mathrm{N}=3057 \text { for primary } \\
\text { efficacy outcome at D } 35) \\
\text { (N: } 4001 \text { for safety outcome }\end{array}$ & - & - & - & $\begin{array}{l}\text { Day 10: } 2.7 \% \\
\text { Day 35: } 5.7 \%\end{array}$ & $\begin{array}{l}\text { Day 10: } 1.2 \% \\
\text { Day 35: } 1.7 \%\end{array}$ \\
\hline Statistics & - & - & - & $\begin{array}{l}\text { Day 10: } \\
\text { RR }(95 \% \mathrm{CI}): 0.97 \text { ( } 0.71 \text { to } \\
1.31) \\
\text { Day 35: } \\
\text { RR }(95 \% \mathrm{CI}): 0.77 \text { ( } 0.62 \text { to } \\
0.96)\end{array}$ & $\begin{array}{l}\text { Day 10: } \\
\text { RR }(95 \% \mathrm{CI}): 2.30 \text { (1.63 to } \\
3.17) \\
\text { Day 35: } \\
\text { RR }(95 \% \mathrm{CI}): 2.50 \text { (1.85 to } \\
3.25)\end{array}$ \\
\hline EXCLAIM & $\begin{array}{l}\text { Randomized, parallel, } \\
\text { placebo-controlled trial }\end{array}$ & $\begin{array}{l}\text { Acutely ill medical patients } \\
40 \text { years or older with } \\
\text { recently reduced mobility }\end{array}$ & $\begin{array}{l}\text { Not meeting rigidly defined } \\
\text { inclusion criteria }\end{array}$ & $\begin{array}{l}\text { Incidence of VTE up to } \\
\text { day } 28\end{array}$ & Major bleeding \\
\hline $\begin{array}{l}\text { Enoxaparin } 40 \mathrm{mg} \text { daily } \\
(\mathrm{N}: 2975)\end{array}$ & - & - & - & $2.5 \%$ & $0.8 \%$ \\
\hline $\begin{array}{l}\text { Placebo } \\
(\mathrm{N}: 2988)\end{array}$ & - & - & - & $4 \%$ & $0.3 \%$ \\
\hline Statistics & - & - & - & $\begin{array}{l}\text { Absolute risk difference } \\
\text { favoring enoxaparin, }-1.53 \% \text {; } \\
95.8 \% \text { CI, }-2.54 \% \text { to }-0.52 \%\end{array}$ & $\begin{array}{l}\text { Absolute risk difference } \\
\text { favoring placebo, } 0.51 \% \text {; } \\
95 \% \text { CI, } 0.12 \% \text { to } 0.89 \%\end{array}$ \\
\hline
\end{tabular}


enoxaparin group, respectively (RR: 0.85; 95\% CI: 0.73-0.98). Looking at the overall safety population, $0.7 \%$ of the patients in the betrixaban group and $0.6 \%$ of the enoxaparin group suffered from major bleeding (RR: $1.19 ; 95 \%$ CI: 0.67-2.12). In conclusion, extended-duration betrixaban was not superior to the standard regimen of enoxaparin for the prevention of VTE in acutely ill medical patients with an elevated d-dimer level. However, a benefit of betrixaban was observed in the second cohort and in the overall population. This could be attributed to the fact that the first cohort had fewer patients, which resulted in diminished statistical power, compared to the second cohort and the overall population [21].

\section{Conclusion}

Betrixaban is the first and only oral once-daily factor Xa inhibitor, approved by the FDA under Priority Review, for hospital and extended duration prophylaxis ( 35 to 42 days) of VTE in hospitalized acutely ill medical patients at risk for thromboembolic complications due to moderately or severely restricted mobility and other risk factors for VTE. The prespecified exploratory analyses from APEX study showed evidence suggesting betrixaban provided a benefit in the two larger cohorts, with a better safety profile compared to other factor $\mathrm{Xa}$ inhibitors. More data are needed to determine the long-term tolerability of betrixaban.

\section{Acknowledgment}

Author has no conflict of interest

\section{References}

1. Turpie AG (2007) Extended duration of thromboprophylaxis in acutely ill medical patients: optimizing therapy. $J$ Thromb Haemost 5: 5-11.

2. Geerts WH, Pineo GF, Heit JA, Bergqvist D, Lassen MR, et al. (2004) Prevention of venous thromboembolism: the Seventh ACCP Conference on Antithrombotic and Thrombolytic Therapy. Chest 126: 338S-400S. [Crossref]

3. Alikhan R, Cohen AT, Combe S (2004) Risk factors for venous thromboembolism in hospitalized patients with acute medical illness: analysis of the MEDENOX Study. Arch Intern Med 164: 963-968.

4. Heit JA, O'Fallon WM, Petterson TM (2002) Relative impact of risk factors for deep vein thrombosis and pulmonary embolism: a population-based study. Arch Intern Med 162: $1245-1248$

5. Baser O, Liu X, Phatak H (2013) Venous thromboembolism prophylaxis and clinical consequences in medically ill patients. Am J Ther 20: 132-142.
6. Goldhaber SZ (2010) Risk factors for venous thromboembolism. J Am Coll Cardiol 56: 1-7. [Crossref]

7. Tapson VF, Decousus H, Pini M (2007) Venous thromboembolism prophylaxis in acutely ill hospitalized medical patients: findings from the International Medical Prevention Registry on Venous Thromboembolism. Chest 132: 936-945.

8. Spencer FA, Lessard D, Emery C, Reed G, Goldberg RJ (2007) Venous thromboembolism in the outpatient setting. Arch Intern Med 167: 1471-1475. [Crossref]

9. Hull RD, Merali T, Mills A, Stevenson AL, Liang J (2013) Venous thromboembolism in elderly high-risk medical patients: time course of events and influence of risk factors. Clin Appl Thromb Hemost 19: 357-362. [Crossref]

10. Rickles FR, Hair GA, Zeff RA, Lee E, Bona RD (1995) Tissue factor expression in human leukocytes and tumor cells. Thromb Haemost 74: 391-395. [Crossref]

11. Yu JL, May L, Lhotak V (2005) Oncogenic events regulate tissue factor expression in colorectal cancer cells: implications for tumor progression and angiogenesis. Blood 105: 1734-1741.

12. Ridker PM, Rifai N, Pfeffer MA (1998) Inflammation, pravastatin, and the risk of coronary events after myocardial infarction in patients with average cholesterol levels. Cholesterol and Recurrent Events (CARE) Investigators. Circulation 98: 839-844.

13. Hamid T, Gu Y, Ortines RV (2009) Divergent tumor necrosis factor receptor-related remodeling responses in heart failure: role of nuclear factor-kappaB and inflammatory activation. Circulation 119: 1386-1397.

14. de Francisco AL, Stenvinkel P, Vaulont S (2009) Inflammation and its impact on anaemia in chronic kidney disease: from haemoglobin variability to hyporesponsiveness. $N D T$ Plus 2: i18-18i26. [Crossref]

15. Agusti A, Edwards LD, Rennard SI (2012) Persistent systemic inflammation is associated with poor clinical outcomes in COPD: a novel phenotype. PloS One 7: e37483.

16. Goldhaber SZ, Leizorovicz A, Kakkar AK, Haas SK, Merli G, et al. (2011) Apixaban versus enoxaparin for thromboprophylaxis in medically ill patients. $N$ Engl J Med 365: 2167-2177. [Crossref]

17. Hull RD, Schellong SM, Tapson VF (2010) Extended-duration venous thromboembolism prophylaxis in acutely ill medical patients with recently reduced mobility: a randomized trial. Ann Intern Med 153: 8-18.

18. Cohen AT, Spiro TE, Spyropoulos AC; MAGELLAN Steering Committee (2013) Rivaroxaban for thromboprophylaxis in acutely ill medical patients. $N$ Engl J Med 368 : 1945-1946. [Crossref]

19. Sharma A, Chatterjee S, Lichstein E, Mukherjee D (2012) Extended thromboprophylaxis for medically ill patients with decreased mobility: does it improve outcomes? J Thromb Haemost 10: 2053-2060.

20. Betrixaban (2017) Portola Pharmaceuticals, Inc. South San Francisco, CA

21. Cohen AT, Harrington RA, Goldhaber SZ, Hull RD, Wiens BL, et al. (2016) Extended Thromboprophylaxis with Betrixaban in Acutely Ill Medical Patients. $N$ Engl J Med 375: 534-544. [Crossref]

Copyright: (C2017 Almalki O. This is an open-access article distributed under the terms of the Creative Commons Attribution License, which permits unrestricted use, distribution, and reproduction in any medium, provided the original author and source are credited. 